\title{
ASIAN GAMES 2014: IMPLEMENTASI BHINNEKA TUNGGAL IKA MELALUI OLAH RAGA
}

\author{
Ascosenda Ika Rizqi \\ Fakultas Ekonomi, Universitas Merdeka Pasuruan \\ Email: Senda.air@gmail.com
}

\begin{abstract}
Indonesia is a country that has a very high level of pluralism and a complex level of social plurality. The Indonesian nation has been aware of the diversity of languages, cultures, religions, ethnicities and ethnicities, the understanding of the value of Unity in Diversity in Indonesian society can be manifested integrally with the cooperation of all components of the nation, both by the government as the organizer of the country and each individual's private citizens. Asian Games is the biggest moment of the Asian nation, especially in the field of sports that have been held since the 1950s. The 2014 Asian Games is certainly not only a matter of sports from various branches, but for a moment as an Indonesian citizen there is certainly a spirit of unity in diversity in its implementation.
\end{abstract}

Keywords: Bhinneka Tunggal Ika; Asian Games; Sport

\section{PENDAHULUAN \\ BHINNEKA TUNGGAL IKA}

Indonesia merupakan negara yang memiliki tingkat kemajemukan masyarakatnya yang sangat tinggi dan tingkat pluralitas sosial yang sangat kompleks. Dalam masyarakat Indonesia yang majemuk itu, ada dua istilah yang penting dipahami yaitu kemajemukan (pluralitas) dan keanekaragaman (heterogenitas). Pluralitas sebagai kontraposisi dari singularitas mengindikasikan adanya suatu situasi yang terdiri dari kejamakan, dan bukan ketunggalan (Kusumohamidjojo, 2000). Artinya, dalam "masyarakat Indonesia" dapat dijumpai berbagai subkelompok masyarakat yang tidak bisa disatu kelompokkan satu dengan yang lainnya. Adanya tidak kurang dari 500 suku bangsa di Indonesia menegaskan kenyataan itu. Demikian pula halnya dengan kebudayaan mereka. Sementara heterogenitas yang merupakan kontraposisi dari homogenitas mengindikasikan suatu kualitas dari keadaan yang menyimpan ketidaksamaan dalam unsur-unsurnya.

Menurut Undang-Undang Dasar Republik Indonesia tahun 1945 pasal 36A berbunyi "Lambang Negara ialah Garuda Pancasila dengan semboyan Bhinneka
Tunggal Ika", hal tersebut sangat jelas bahwa Bhinneka Tunggal Ika merupakan semboyan bangsa Indonesia. Semboyan ini tertulis di dalam lambang negara Indonesia, Burung Garuda Pancasila. Pada kaki Burung Garuda itulah terpampang dengan jelas tulisan Bhinneka Tunggal Ika. Pursika (2009) juga menambahkan bahwa Semboyan "Bhinneka Tunggal Ika" memuat dua konsep yang berbeda, bahkan kedua konsep tersebut seolaholah bersifat kontradiktif. Kedua konsep itu adalah "Bhinneka" dan "Tunggal Ika". Konsep "Bhinneka" mengakui adanya keanekaan atau keragaman, sedangkan konsep "Tunggal Ika" menginginkan adanya kesatuan. Keanekaan dicirikan oleh adanya perbedaan, sedangkan kesatuan dicirikan oleh adanya kesamaan. Jika kedua hal tersebut dipahami dan dilaksanakan dengan tekanan yang berbeda (tidak seimbang), maka akan dapat menimbulkan kondisi yang berbeda pula. Manakala segi keanekaan yang menonjolkan unsur perbedaan itu ditampilkan secara berlebihan, maka kemungkinan munculnya konflik tak terhindarkan. Sebaliknya, manakala segi kesatuan yang menonjolkan kesamaan 
itu ditampilkan secara berlebihan, maka tindakan itu tergolong melanggar kodrat perbedaan, karena perbedaan adalah kodrat sekaligus berkah yang tak terelakkan. Adanya dua konsep yang berbeda tersebut menunjukkan bahwa semboyan "Bhinneka Tunggal Ika" mengandung problem metafisika, yaitu problem antara kepelbagaian dan kesatuan, problem antara hal banyak (the many) dan hal satu (the one). Berdasarkan masalah tersebut tampak bahwa untuk mencari makna "Bhinneka Tunggal Ika" diperlukan adanya perenungan mendalam yang bersifat filosofis metafisis.

Bhinneka Tunggal Ika merupakan motto atau semboyan Indonesia. Kata bhinneka berarti "beraneka ragam" atau berbeda-beda. Kata neka dalam bahasa Sanskerta berarti "macam" dan menjadi pembentuk kata "aneka" dalam Bahasa Indonesia. Kata tunggal berarti "satu". Kata ika berarti "itu". Secara harfiah Bhinneka Tunggal Ika diterjemahkan "Beraneka Satu Itu", yang bermakna meskipun berbeda-beda tetapi pada hakikatnya bangsa Indonesia tetap adalah satu kesatuan. Semboyan ini digunakan untuk menggambarkan persatuan dan kesatuan Bangsa dan Negara Kesatuan Republik Indonesia yang terdiri atas beraneka ragam budaya, bahasa daerah, ras, suku bangsa, agama dan kepercayaan. Sujanto (2009) juga menjelaskan bahwa sesanti (kalimat Bijak; wise-word) Bhinneka Tunggal Ika yang dipelihara dan digunakan sebagai pedoman atau sumber kajian di masyarakat. Bhinneka Tunggal Ika merupakan kalimat (sesanti) yang tertulis di pita lambang Garuda Pancasila yang berbagai keragaman etnis, agama, adat-istiadat, bahasa daerah, budaya dan lainnya yang mewujudkan untuak menjadi satu tanah air, satu bangsa dan satu bahasa Indonesia.

Menurut Mahfud (2009) pada hakikatnya sejak awal para pendiri bangsa Indonesia telah menyadari akan keragaman bahasa, budaya, agama, suku dan etnis,
Pemahaman nilai Bhinneka Tunggal Ika dalam masyarakat Indonesia dapat wujud secara integral dengan kerjasama seluruh komponen bangsa, baik oleh pemerintah selaku penyelenggara negara maupun setiap insan pribadi warga. Peningkatan sosialisasi aktualisasi pemahaman nilainilai ke-Bhinneka Tunggal Ika-an harus dilakukan melalui tindakan nyata dalam kehidupan keseharian seluruh kompenen warga dalam rangka memperkuat integrasi nasional, karena Indonesia dengan keberagaman budaya, suku/etnik, bahasa, agama, kondisi geografis, dan strata sosial yang berbeda. Indonesia dengan gambaran masyarakat majemuk yang terdiri dari suku-suku bangsa yang berada di bawah kekuasaan sebuah sistem nasional, termasuk di dalamnya pemerintah yang menjalankan proses pembangunan masyarakat harus bersinergis untuk bersama-sama dengan rakyat tanpa membedakan keberagaman budaya, bahasa, agama, suku/etnik, dan bahkan strata sosial, mewujudkan citacita bangsa sesuai dengan komitmen bersama, berlandaskan nilai-nilai yang terkandung dalam ke-Bhinneka Tungal Ikaan yang termaktub dalam Pancasila. Ciri kemajemukan masyarakat Indonesia yang terintegrasi secara nasional adalah sangat penting sebagai kekayaan dan merupakan potensi yang dapat dikembangkan sehingga dapat dimanfaatkan dalam sistem komunikasi sebagai acuan utama bagi menunjukkan jati diri bangsa Indonesia sebagai nasionalisme.

KalimatBhinneka Tunggal Ika sendiri diambil dari penggalan Sumpah Palapa yang dikumandangkan oleh Patih Gajah Mada dalam usaha penaklukan nusantara di masa keemasan Kerajaan Majapahit. Sumpah Palapa kemudian menjadi dasar bagi terciptanya Sumpah Pemuda pada 28 oktober 1928. Ketika Sumpah Pemuda diikrarkan, saat itulah Indonesia sebenarnya telah melebur menjadi sebuah bangsa Indonesia dan melepaskan diri dari segala bentuk ide kepulauan, ide kesukuan dan sebagainya 
(Setyani, 2009). Bhinneka Tunggal Ika sering diartikan sebagai 'berbeda-beda tetapi tetap satu'. Dalam perjalanan kemerdekaan Indonesia, frasa ini sering muncul dalam nuansa makna yang berbedabeda. Keberagaman dan persatuan muncul sebagai atribut yang melekat dalam semangat Bhinneka Tunggal Ika. Nuansa perbedaan makna itulah yang ingin diangkat dalam tulisan ini. Menurut penulis, nuansa perbedaan makna tersebut didasari oleh adanya perbedaan cara pandang atau yang populer disebut sebagai paradigma. Pursika (2009) juga menjelaskan bahwa Untuk menjaga keberlangsungan hidup berbangsa, kebhinnekaan sebaiknya tidak dipandang sebagai ancaman, tetapi kebhinnekaan harus dipandang sebagai aset yang diharapkan mampu berperan sebagai sumber kekayaan bagi bangsa Indonesia. Kebhinnekaan sebagai kekayaan serta mendaya-gunakannya justeru dapat menjadi pondasi kokoh persatuan dari sebuah imagined community yang bernama Negara Kesatuan Republik Indonesia. Kesadaran sebagai masyarakat yang berbhinneka tetapi mencita-citakan kesatuan yang dikukuhkan sebagai konsensus bersama dalam Soempah Pemuda 1928 telah menjadi modal sosial ampuh yang berhasil mempersatukan dan mengantar negara-bangsa ini mampu melewati masa-masa sulit dari dulu sampai sekarang, bahkan juga nanti.

Pandangan Paradigma positivis menurut Sarantakos (1995) menekankan masyarakat memiliki nilai universal sebagai pengikat dan dengan demikian ada penyeragaman nilai dalam masyarakat. Dengan pemahaman tersebut, dapat dikatakan terdapat beberapa situasi dan kondisi dalam beberapa periode dimana Indonesia menerapkan cara pandang demikian dalam memaknai Bhinneka Tunggal Ika. Kondisi ini sangat amat terlihat pada masa Orde Baru, dimana berbagai macam aspek kehidupan sangat terpusat pada satu titik, yaitu rezim Orde
Baru itu sendiri. Pemusatan ini berujung pada pengontrolan secara ketat terhadap masyarakat. Pengontrolan terjadi tidak hanya pada bidang politik atau ekonomi semata, namun pengontrolan juga terjadi pada norma dan nilai yang berkembang pada masyarakat. Dengan fokus utama dari rezim orde baru yang menekankan kestabilan politik, Bhinneka Tunggal Ika sebagai semboyan negara juga tentu saja dikontrol maknanya oleh rezim Orde Baru. Konsep Bhinneka Tunggal Ika yang memiliki dua sisi yaitu persatuan dan keragaman oleh rezim orde baru maknanya lebih ditekankan pada persatuan. Bahkan bukan hanya makna persatuan yang dijalankan dan ditekankan oleh rezim orde baru, melainkan Tunggal Ika itu dimaknai menjadi satu dan seragam.

Persatuan yang ditandai dengan stabilitas sosial sangat kental dalam periode Orde Baru. Stabilitas sosial sangat penting dalam periode ini, karena kestabilan dimaknai sebagai awal dari pembangunan. Untuk menciptakan kestabilan tersebut, maka masyarakat harus diseragamkan agar dapat dikontrol dan terjadi pemerataan nilai-nilai yang menunjang tujuan tersebut. Sosialisasi nilai misalnya terjadi di semua lini masyarakat, baik di tingkat dasar seperti sekolahsekolah dan di tingkat yang lebih tinggi seperti di kantor-kantor. Penyeragaman nilai-nilai yang "disepakati" ini menjadi standar normatif dan difungsikan sebagai perekat atau penyatu masyarakat. Bhinneka Tunggal Ika, yang menekankan pentingnya Tunggal Ika terjadi pada periode ini. Oleh karenanya, masa itu diwarnai dengan kebijakan-kebijakan yang mengarah pada persatuan dan berlaku untuk seluruh masyarakat. Masyarakat dilihat harus mengalami kemajuan yang sama dengan negara-negara yang dianggap maju, dan diasumsikan dengan mengikuti cara yang sama dengan pemikiran negara maju, maka Indonesia akan mencapai kesuksesan yang serupa. Lokalitas tidak dipentingkan dalam periode ini. Oleh 
karena itu, kebijakan-kebijakan seperti Repelita yang mengacu pada Tahapan Pertumbuhan Ekonomi Rostow misalnya sangat amat modernis. Pemikiran ini sejalan dengan pemikiran positivis Comte yang melihat bahwa setiap masyarakat akan melalui jenjang yang sama.

Berdasarkan pemikiran inilah, proses Tunggal Ika, penyatuan seluruh masyarakat melalui penyeragaman nilai menjadi penting. Bhinneka Tunggal Ika dimaknai sebagai keberagaman yang harus disatukan menjadi sebuah identitas nasional. Dengan ciri-ciri termanifes dalam nilainilai yang diseragamkan, kesatuan bangsa yang utuh akan tercapai. Penyeragaman nilai bahwa kita adalah satu, atau kita adalah sama (satu nusa, satu bangsa dan satu bahasa) akan menjadi identitas nasional bangsa. Demi tujuan itu, segala cara harus digunakan termasuk cara represif sehingga setiap anggota masyarakat yang menunjukkan perbedaan dianggap bertentangan dan harus ditertibkan.

Kesatuanwilayahjugamenjadi cirikhas dalam periode ini. Kebijakan transmigrasi adalah salah satunya. Dengan dilakukan transmigrasi memindahkan pendudukan dari pulau padat penduduk ke pulau jarang penduduk, seperti dari Jawa ke Sumatera, Kalimantan atau Sulawesi adalah sebuah cara agar terjadi kesatuan dan perasaan memiliki yang tinggi terhadap Indonesia sebagai sebuah kesatuan negara. Negara berdaulat, bersatu dan melebur merupakan ciri-ciri pesan yang mengutamakan Tunggal Ika. Kemajemukan bangsa ada namun tidak dimaknai penting karena persatuan dan kesatuan bangsa dan negara dianggap lebih penting dalam proses kemajuan bangsa (memodernkan bangsa).

Tinjauan Paradigma Interpretif dalam memandang Bhinneka Tunggal Ika. Paradigma ini dapat dikatakan sebagai anti tesis dari paradigma positivistik. Oleh karenanya, maka terdapat pemaknaan berbeda dalam menginterpretasi pesan dalam semboyan Bhinneka Tunggal Ika. Bila paradigma positivis menekankan Tunggal Ika dalam Bhinneka Tunggal Ika, maka paradigma interpretif lebih memaknai pentingnya Bhinneka dalam semboyan tersebut. Dapat dikatakan dalam paradigma ini, multikulturalisme atau kemajemukan masyarakat atau keberagaman atau pluralisme menjadi penting walaupun tetap disatukan dalam sebuah sistem nasional. Paradigma ini menekankan adanya pengakuan dan penghargaan pada kesederajatan perbedaan budaya. Perbedaan budaya adalah sebuah realitas sosial yang nyata dan dialami secara berbeda oleh setiap masyarakat yang berbeda. Dengan keragaman suku bangsa dan ras dan agama di Indonesia, maka dalam paradigma interpretif, budaya tidak dapat digeneralisasikan.

Selain budaya tidak dapat digeneralisir, dalam kerangka berpikir paradigma ini penyeragaman nilai menjadi tidak masuk akal. Identitas nasional dalam kerangka berpikir ini hanya akan tercapai bila bangsa Indonesia justru mengedepankan perbedaan budaya tersebut. Menurut Wisnumurti (2010), multikulturalisme mengedepankan prinsip keterbukaan, kesetaraan, keadilan dan penghormatan atas perbedaan, sangat sejalan dengan nilai-nilai Bhinneka Tunggal Ika, oleh karena itu, menjadi sangat penting untuk dijadikan dasar dalam memperkuat solidaritas sosial dan kebangsaan sebagai konstruksi dalam memperkokoh persatuan dan kesatuan bangsa. Paradigma yang demikian sangat kental terasa ketika Indonesia memasuki masa reformasi. Dalam masa ini, keragaman menjadi satu isu yang penting setelah selama tiga dasawarsa masa orde baru isu keragaman seperti terpinggirkan, dikalahkan oleh isu persatuan, kesatuan, keseragaman. Keragaman dalam masa reformasi ini terlihat dalam berbagai bidang. Dalam bidang politik misalnya keragaman sangat kental terlihat dengan diberlakukannya otonomi daerah sebagai 
tata kelola negara. Dalam bidang budaya keragaman diperlihatkan terutama melalui diakuinya tahun baru suatu etnis sebagai hari libur nasional. Dalam bidang pendidikan, keragaman dalam masa reformasi ditandai dengan tumbuh suburnya sekolah-sekolah yang berwawasan komunitas dan lokalitas masing-masing tempat. Walaupun masih banyaknya hambatan, namun Bhinneka Tunggal Ika yang menekankan keragaman seperti halnya paradigma interpretif banyak dapat dilihat dalam masa reformasi.

Paradigma kritis memandang suatu realitas sosial sebagai realitas yang semu. Dalam paradigma ini, suatu realitas sosial dianggap memiliki berbagai lapisan yang jika dikupas semakin dalam maka akan terbongkar lapisan-lapisannya. Seperti yang telah disebutkan dalam bagian sebelumnya, paradigma positivis menekankan universalisme dan keseragaman, sehingga bila digunakan untuk menelaah Bhinneka Tunggal Ika maka penekanan Bhinneka Tunggal Ika adalah pada Tunggal Ika atau satu dan seragam. Dan seperti juga telah disebutkan sebelumnya, jika menggunakan paradigma interpretif, maka pembahasan mengenai Bhinneka Tunggal Ika akan menitikberatkan pada Bhinnekanya atau keragamannya. Namun apabila Bhinneka Tunggal Ika dikaji dengan menggunakan paradigma kritis, realitas yang berupa terjadi penekanan pada Bhinneka atau realitas berupa penekanan pada Tunggal Ika hanyalah realitas yang semu. Kedua realitas yang ada tersebut hanyalah lapisan paling luar dari apa yang terlihat dan dirasakan.

Penggunaan paradigmakritismenurut Salim (2006) yang menganggap untuk memahami suatu realitas yang diperlukan adalah membongkar realitas semu yang ada; sehingga dalam menelaah Bhinneka Tunggal Ika akan membongkar realitasrealitas yang ada. Dengan menggunakan pendekatan kritis ini, kondisi dimana penerapan Bhinneka Tunggal Ika lebih menekankan kesatuan dan keseragaman dianggap sebagai satu lapisan terluar dari kenyataan atau realitas sosial yang sesungguhnya terjadi. Dengan paradigma kritis ini, kondisi yang ada tersebut harus dibongkar dengan mengajukan asumsiasumsi yang mempertanyakan kondisi yang ada tersebut. Misalnya saja jika kita melihat pada masa orde baru yang menekankan kesatuan dan penyeragaman, maka harus dipertanyakan mengapa hal demikian terjadi, siapa yang mendapatkan keuntungan dengan kondisi yang demikian itu, apakah mungkin kodisi demikian diciptakan negara untuk memobilisasi rakyat demi pembangunan, dan lain sebagainya.

Apabila Bhinneka Tunggal Ika dalam satu masa dalam sejarah Indonesia ini dianggap menekankan ke-bhinnekaannya, maka dengan paradigma kritis perlu pula dijelaskan mengapa itu terjadi dan untuk kepentingan pihak atau kelompok mana kondisi demikan itu terjadi. Misalnya dengan melihat pada masa reformasi dimana penekanan Bhinneka Tunggal Ika hanya pada bhinneka-nya maka perlu dilihat mengapa hal ini terjadi, bisa saja kondisi demikian terjadi. karena negara memang melihat bahwa pada masa reformasi masyarakat sudah lelah dengan penyeragaman sehingga apabila negara pada masa reformasi tetap memberlakukan penyeragaman,makatentanganakanbanyak terjadi terhadap negara. Sebaliknya jika negara lebih mengedepankan keragaman, maka masyarakat akan memihak pada negara, dan dengan demikian negara akan memperoleh legitimasi dari rakyat.

\section{METODE}

Metode yang digunakan dalam artikel ini adalah kajian literatur untuk menganalisis implementasi Bhinneka Tunggal Ika melalui olah raga dalam hal ini adalah ajang Asian Games. Analisis data dilakukan dengan memadukan kebenaran obyektif dari data dari buku dan media massa. 


\section{HASIL DAN PEMBAHASAN}

Menurut Rasyid (2009) dalam Undang-Undang Republik Indonesia Nomor 3 tahun 2005 menjelaskan bahwa Pemerintah, dalam hal ini Kementerian Negara Pemuda dan Olahraga, melalui Deputi III, Bidang Kewirausahaan Pemuda dan Industri Olahraga, mulai menata langkahlangkah konkret untuk mengembangkan industri olahraga dalam rangka mendorong tumbuhnya olahraga pendidikan, olahraga prestasi, dan olah-raga rekreasi, untuk mendorong tumbuhnya industri dan ekonomi nasional yang menyejahterakan masyarakat, dan untuk menanggulangi pengangguran, membuka peluang kerja dan usaha bagi wirausaha.Industriolahragayang berbentuk sarana dan prasarana yang diproduksi, diperjualbelikan, dan/atau disewakan untuk masyarakat belum berjalan seperti yang diharapkan karena banyak faktor, di antaranya keterbatasan modal dan kesulitan memasarkan produk. Misalnya, perlengkapan olahraga produk lokal, seperti pakaian dan sepatu, tentu akan kalah bersaing dengan produk luar dengan merek tertentu, seperti adidas, nike, puma, lotto, dan reebok. Masyarakat sudah mempunyai brand image dan fanatisme yang luar biasa terhadap produkproduk dari luar tersebut yang seakanakan dapat mengangkat harga dirinya jika memakai produk-produk tersebut. Industri olahraga yang berbentuk jasa penjualan kegiatan cabang olah raga nasibnya tidak lebih baik daripada industri olahraga yang berbentuk barang. Kenyataan di lapangan menunjukkan belum semua event cabang olahraga dapat menghasilkan keuntungan finansial, seperti yang terjadi dalam cabang sepak bola. Panigoro (2011) juga menjelaskan bahwa industri sepak bola di Indonesia dapat mencapai angka Rp 3 triliun yang mampu memberikan kontribusi bagi ekonomi nasional. Setiap ada event sepak bola, baik tingkat daerah, nasional, maupun internasional, tidak pernah sepi penonton.
Asian Games merupakan momen terbesar bangsa Asia khususnya dalam bidang olahraga yang sudah diselenggarakan sejak tahun 1950an, di tahun 2014 Asian Games diadakan di Incheon, Korea Selatan. Asian Games 2014 atau Pesta Olahraga Musim Panas Asia 2014 adalah edisi ke17 dari acara multi event olahraga regional Asia yang diselenggarakan di IncheonKorea Selatan pada tanggal 18 September 2014 hingga 4 Oktober 2014. Asian Games 2014 mempertandingkan sebanyak 36 cabang olahraga. Slogan Asian Games 2014 yaitu 'Diversity Shines Here', lebih dari 14 ribu atlit dan staf dari 45 negara berkompetisi memperebutkan 439 medali di 36 cabang olahraga.

Emblem yang diumumkan oleh IAGOC (Incheon Asian Games Organization Committee) sebagai penyelenggaran Asian Games 2014 memiliki makna sebagai berikut: pertama, konsep desain. Huruf A merupakan isial dari Asia yang membentuk formasi manusia mengilustrasikan tangan orang Asia bergandengan tangan dan membentuk sayap. Sedangkan lambang matahari cerah (simbol OCA dan Asian Games) memiliki makna sebuah pergerakan yang konstan menuju masa depan yang cerah. Pesan yang ingin disampaikan adalah harapan agar masyarakat Asia membangun persahabatan dan harmono melalui ajang Asian Games 2014. Kedua, elemen warna. Terdapat campuran warna biru dan hijau yang memiliki arti masa depan yang cerah dan harapan dari Incheon. Warna hijau melambangkan pertumbuhan berkelanjutan dari Incheon yang merupakan perpaduan yang koheren antara alam dan manusia. Sedangkan warna biru melambangkan langit, laut serta kota Incheon yang maju serta menggambarkan keinginannya menjadi kota dunia. Ketiga, elemen huruf. Huruf yang ditulis dalam bentuk Gothic dan biru gelap memberikan arti sebuah kedinamisan dan perkembangan ke depan dari Incheon dalam hubungannya dengan 
negara-negara di Asia (Hutagalung, 2016).

Maskot dari Asian Games 2014 adalah tiga seal atau anjing laut. Ketiga seal tersebut bernama Barame, Chumuro dan Vichuon yang memiliki makna angin, tarian dan cahaya. Pertama, Barame atau cahaya. Hal ini melambangkan cahaya harapan brsinar di dunia. Kedua, Chumuro atau tarian. Hal ini memiliki arti untuk memperkenalkan Asian Games kepada dunia luas. Ketiga, Vichuon atau cahaya. Hal ini berarti melalui ajang Asian Games diharapkan sesama bangsa Asia bisa menjalin hubungan yang harmonis dan hangat.

Sebagai warga negara Indonesia seyogyanya kita juga harus ikut andil dalam mendukung kegiatan Asian Games yang diikuti oleh atlet-atlet terbaik negara Indonesia, selain itu sebagai masyarakat Indonesia juga wajib mendukung perjuangan para pahlawan olahraga di pentas 4 tahunan tersebut. Esesnsi dari event Asian Games sebenarnya tidak selalu berkaitan dengan medali saja. Asian Games merupakan sebuah kebanggan bagi negara Indonesia karena para putra putri terbaik bangsa membawa semangat yang tinggi dalam mengharumkan nama Indonesia. Dalam Asian Games para atlet harus memiliki sikap sportif, fair play, dan semangat tim yang membara. Oleh karena itu sebagai negara yang ber-Bhinneka Tunggal Ika kita wajib mendukung mereka di kancah Asian Games 2014.

Membicarakan Asian Games 2014 ini tentunya tidak hanya masalah olahraga dari berbagai cabang, namun sejenak sebagai warga negara Indonesia tentunya ada semangat ber-bhinneka tunggal ika dalam implementasinya, sejenak kita bisa melupakan perbedaan, sejenak kita bisa melupakan rasa hedonisme terhadap daerah masing-masing, semua berbaur menjadi satu mengibarkan bendera merah putih di arena olahraga, seluruh lapisan masyarakat Indonesia memanfaatkan momen Asian Games 2014 sebagai pemersatu bangsa melalui pentas olahraga yang tentu dalam 20 tahun ke depan belum tentu bisa dinikmati seperti saat ini. Mengingat kembali dimana Indonesia juga sukses menjadi juara umum dalam ajang SEA Games 2011 yang dilaksanakan di Jakarta, yang nyatanya juga mampu mempersatukan rasa ke-bhinneka tunggal ika-an kita. Tanpa membedakan suku, agama, warna kulit semuanya menyatu, berbaur meneriakkan dengan lantang kata "Indonesia dan Garuda", inilah bukti bahwa melalui olahraga semangat persatuan, semangat ke-bhinnekaan itu tetap ada dan terus terjaga, melalui dunia olahraga pula pemberitaan negatif tentang bangsa Indonesia tertutupi oleh semangat persatuan dari masyarakat Indonesia pada umumnya.

Sebagai bukti beberapa cabang olahraga yang mampu mempersatukan kebhinnekaan kita sebagai bangsa Indonesia melalui cabang olahraga adalah bagaimana saat tim nasional sepakbola Indonesia berlaga di lapangan hijau, bagaimana riuhnya para penonton di stadion sepakbola dalam mendukung tim kesayangan masyarakat Indonesia, sehingga menimbulkan semangat tersendiri bagi para pemain sepakbola, nyanyian atau chant "garuda di dadaku garuda kebanggaanku, ku yakin hari ini pasti menang..." serta nyanyian atau chant lain yang membuat bulu roma berdiri serta tak jarang air mata menetes karena rasa bangga terhadap tim nasional sepakbola Indonesia, Begitu pula di cabang olahraga lain seperti badminton, melihat antusiasme masyarakat Indonesia dalam mendukung para pemain bulutangkis di Istana Olahraga (Istora) Senayan Jakarta sangat mengharu biru, nyanyian atau chant "Indonesia...Indonesia...Indonesia" membuat suasana yang berbeda sehingga semangat para pemain Bulu Tangkis menjadi tumbuh dan berusaha untuk memberikan yang terbaik bagi bangsa Indonesia, dan masih banyak lagi cabang 
olahraga lain yang mampu membuat cerita tersendiri demi sang merah putih berkibar di podium tertinggi serta membawa terbang garuda di langit tertinggi.

\section{SIMPULAN}

Bhinneka Tunggal Ika merupakan semboyan bangsa Indonesia yang memiliki arti berbeda-beda tetapi tetap satu, dimana kata Bhinneka Tunggal Ika diambil dari bahasa sansekerta, Bhinneka Tunggal Ika sudah melekat dalam sanubari masyarakat Indonesia yang memang secara geografis memiliki keperbedaan mulai dari masyarakat hingga budayanya, namun perbedaan itu bukanlah penghalang bagi Indonesia, namun justru perbedaan itulah yang membuat Indonesia menjadi satu dan kuat. Melalui pesta olahraga se-Asia atau dikenal dengan nama ASIAN Games 2014 rasa ke-bhinnekaan itulah yang justru semakin kuat dan nyata dalam aksinya, melalui olahragalah rasa kebhinnekaan itu tetap ada dan terjaga dengan baik, inilah bukti bahwa Bhinneka Tunggal Ika bukan hanya semboyan yang di cengkram oleh kaki-kaki burng Garuda, namun salah satu implementasi Bhinneka Tunggal Ika akan tetap hidup melalui cabang olahraga.

\section{DAFTAR PUSTAKA}

Hutagalung, Jefry. 2014. Asian Games 2014-Incheon-Korea Selatan: Ketiga KalinyaKoreaSelatanMenyelenggarakan Event Akbar Asian Games. https:// jefrihutagalung.wordpress.com/tag/17thincheon-asian-games-2014/ diakses pada tangga; 15 Agustus 2016

Kusumohamidjojo, B. 2000. Kebhinnekaan Masyarakat Indonesia: Suatu Problematik Filsafat Kebudayaan. Jakarta: Grasindo.

Mahfud,C.2009.Pendidikan Multikultural. Yogyakarta: Pustaka Pelajar.

Panigoro, A. 2011. Industri Sepak Bola Mencapai Rp 3 Triliun. Koran Kompas. (17 Januari 2011). Halaman 29.
Pursika, I Nyoman. 2009. Kajian Analitik Terhadap Bhinneka Tunggal Ika. Jurnal Pendidikan dan Pengajaran, Jilid 42, Nomor 1, April 2009: Universitas Udayana

Rasyid, S. 2009. Menjadikan Industri Olahraga sebagai Tulang Punggung Industri Nasional. http://www. indonesia.go.id diakses pada tanggal 15 Agustus 2016

Salim, Agus. 2006. Teori \& Paradigma Penelitian Sosial. Tiara Wacana. Yogyakarta.

Sarantakos, Sotirios. 1995. Social Research. Macmillan Education Austalia Pty Ltd.

Setyani, Turita Indah. 2009. Bhinneka Tunggal Ika sebagai Pembentuk Jati Diri Bangsa.

Sujanto, B. 2009. Pemahaman Kembali Makna Bhinneka Tunggal Ika (persaudaraan dalam kemajemukan). Jakarta: Sagung Seto

Undang-Undang Dasar Republik Indonesia tahun 1945

Wisnumurti, Anak Agung Gede Oka. 2010. Kesadaran Multicultural dalam Memperkokoh Persatuan. Jakarta 